\title{
Civil construction pathologies
}

\author{
E. D. Reis ${ }^{1 *}$, G. M. Gava ${ }^{2}$, M. A. Souza ${ }^{2}$, B. C. Silva ${ }^{3}$ \\ *Corresponding author: elvysreis@yahoo.com.br
}

\begin{abstract}
${ }^{1}$ Professor, Department of Civil Engineering, Presidente Antônio Carlos University, Barbacena, Brazil ${ }^{2}$ Undergraduate student, Department of Civil Engineering, Presidente Antônio Carlos University, Barbacena, Brazil

${ }^{3}$ Undergraduate student, Dept. of Civil Engineering, Federal University of Minas Gerais, Belo Horizonte, Brazil
\end{abstract}

\begin{abstract}
This work aims to present the main pathologies of civil construction, as well as some constructive or design flaws, besides showing what can be the main procedures of intervention and maintenance. For this, a wide bibliographic review was performed, through the reading and analysis of books, articles, and monographs on such pathologies, being made their due analysis and considerations. It has been demonstrated that there are several mechanisms or processes, from different causes, that can degrade the constructions, that some cares taken in the stages of design and execution of the work can considerably increase the durability of the construction, and that the user also has part of responsibility in the durability and useful life of the building, and should do regular maintenance and be attentive when abnormal characteristics appear. This study concluded that civil construction pathologies can have several causes, and many of them could be avoided if there was regular maintenance of the construction.
\end{abstract}

Keywords: Pathologies; Civil construction; Structural intervention.

\section{RESUMO}

Este trabalho visa apresentar as principais patologias da construção civil, bem como algumas falhas construtivas ou de concepção de projeto, além de mostrar quais podem ser os principais procedimentos de intervenção e manutenção. Para isso, foi realizada uma ampla revisão bibliográfica, por meio da leitura e análise de livros, artigos e monografias sobre tais patologias, sendo feitas as suas devidas análises e considerações. Foi demonstrado que vários são os mecanismos ou processos, de diferentes causas, que podem degradar as construções, que alguns cuidados tomados nas etapas de concepção de projeto e execução da obra podem aumentar consideravelmente a durabilidade da construção, e que o usuário também tem parcela de responsabilidade na durabilidade e vida útil da edificação, devendo fazer uma manutenção regular e ficar atento quando aparecerem características anormais. Este estudo permitiu concluir que as patologias da construção civil podem ter diversas causas, sendo que muitas delas poderiam ser evitadas se existisse uma manutenção regular da construção.

Palavras-chave: Patologias. Construção civil. Intervenção estrutural.

\section{RESUMEN}


Este trabajo tiene como objetivo presentar las principales patologías de la construcción civil, así como algunos defectos constructivos o de diseño, además de mostrar cuáles pueden ser los principales procedimientos de intervención y mantenimiento. Para ello, se realizó una amplia revisión bibliográfica, a través de la lectura y análisis de libros, artículos y monografías sobre dichas patologías, realizándose su debido análisis y consideraciones. Se demostró que existen varios mecanismos o procesos, de diferentes causas, que pueden degradar las construcciones, que algunos cuidados tomados en las etapas de diseño y ejecución de la obra pueden aumentar considerablemente la durabilidad de la construcción, y que el usuario también tiene parte de responsabilidad en la durabilidad y vida útil del edificio, debiendo hacer un mantenimiento regular y estar atento cuando aparezcan características anormales. Este estudio concluye que las patologías de la construcción civil pueden tener varias causas, y muchas de ellas podrían evitarse si hubiera un mantenimiento regular de la construcción.

Palabras clave: Patologías; Construcción civil; Intervención estructural.

\section{INTRODUCTION}

Civil construction is a branch of activity that is growing and modernizing every day, with new technologies, new types of materials, and an increasingly specialized workforce. Its tendency is always to seek solutions to existing problems or, when possible, to avoid these problems occurring already at the beginning of its projects. In addition, civil construction deals with several types of pathologies, which often originate from project and execution failures. In addition to these, some develop over time, which can be the result of natural wear and tear and lack of maintenance.

Thus, it is important to study the main types of pathologies in civil construction, which becomes the objective of this work. It is also convenient to cover some constructive or project conception failures, besides showing what the main intervention and maintenance procedures can be.

Considering that design, construction, and maintenance faults increase the occurrence of pathologies in buildings, it becomes important to study their mechanisms. According to Bertolini (2010), every building has a useful life cycle, which can vary depending on factors such as the durability of the materials used in construction, the conditions of exposure and use, and the existence of periodic maintenance. Therefore, it is up to engineering to develop solutions and ways to prevent this type of problem, which besides generating a bad visual aspect, also generates a negative psychological impact and shows that there is some problem in the construction. Still, according to Castro (2007), the systematic practice of preventive maintenance in a building reduces the costs of corrective actions.

To achieve the listed objectives, a broad literature review was conducted, consulting books, articles and monographs, always giving priority to current works. In this context, a bibliographical research serves as a basis for the theme, making it possible to obtain the material that will be used to carry out the research. The material obtained was read, cataloged, annotated, and then analyzed, with its due considerations.

\section{BIBLIOGRAPHIC REVIEW}

\subsection{Pathological manifestations in foundations}

The materials used in civil construction are of paramount importance, so it is essential to know their deficiencies and vulnerabilities. It is from the correct and optimized use of a material that its 
future behavior is predicted, thus being able to reduce its early deterioration (BERTOLINI, 2010).

Schwirck (2005 apud Macedo, 2017) defines the term foundation as the transition element between the structure and the soil, making the structure subject to the behavior of the soil when subjected to certain loading. In this sense, pathologies in foundations can appear due to several factors, starting in the design phase, compromising the quality of the construction and its useful life. There are also situations in which the soil presents deformations or volumetric variations not caused by the foundation loading, which can result in pathologies.

For this reason, at the beginning of construction, it is essential to choose well the materials that will be used and to observe, besides their mechanical aspects (stress versus deformation, elasticity limit, etc.), their behavior in relation to the environment (water absorption, thermal expansion coefficient, etc.). In this case, the designer must define well the properties of the materials, trying to ensure that these properties actually occur. During construction, quality controls must be provided to allow checking the proper use of the materials that arrive at the construction sites and their correct use (BERTOLINI, 2010).

About pathologies, Oliveira (2013) also notes that in general, pathologies do not have their origin concentrated in isolated factors but suffer the influence of a set of variables, which can be classified according to the pathological process, the symptoms, the cause that generated the problem, or even the stage of the production process in which they occur, besides also pointing to failures in the quality control system proper to one or more activities.

Gonçalves (2015) also explains that the causes of pathologies in buildings are mainly concentrated in "project conception failures, poor quality materials, errors in execution, use for purposes other than those calculated in the project, and lack of maintenance over time.

\subsubsection{Soil settling}

According to Militisky et. al. (2015), the pathologies called settlements or densification have a duration time measured in years, being a process in which occurs the reduction of the soil volume due to compression in the clay, generating excess pore pressures, which leads to settlements that affect the superstructure, as can be seen in Figure 1 and Figure 2.

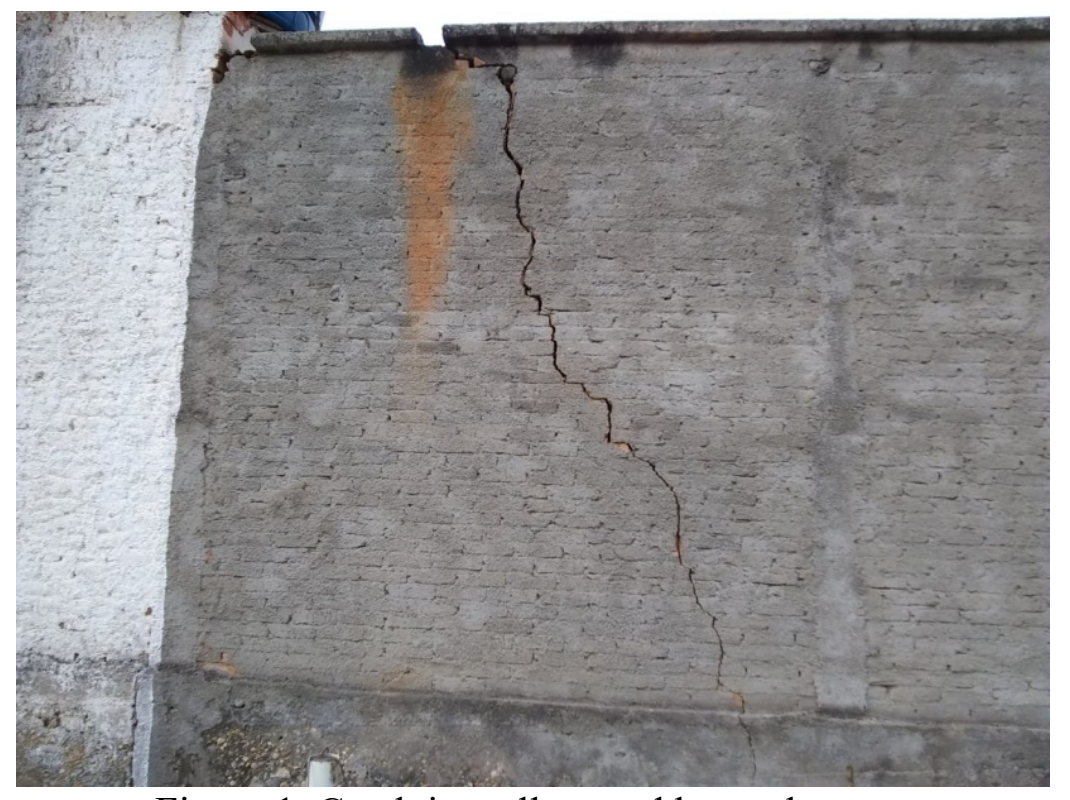

Figure 1. Crack in wall caused by settlement. 


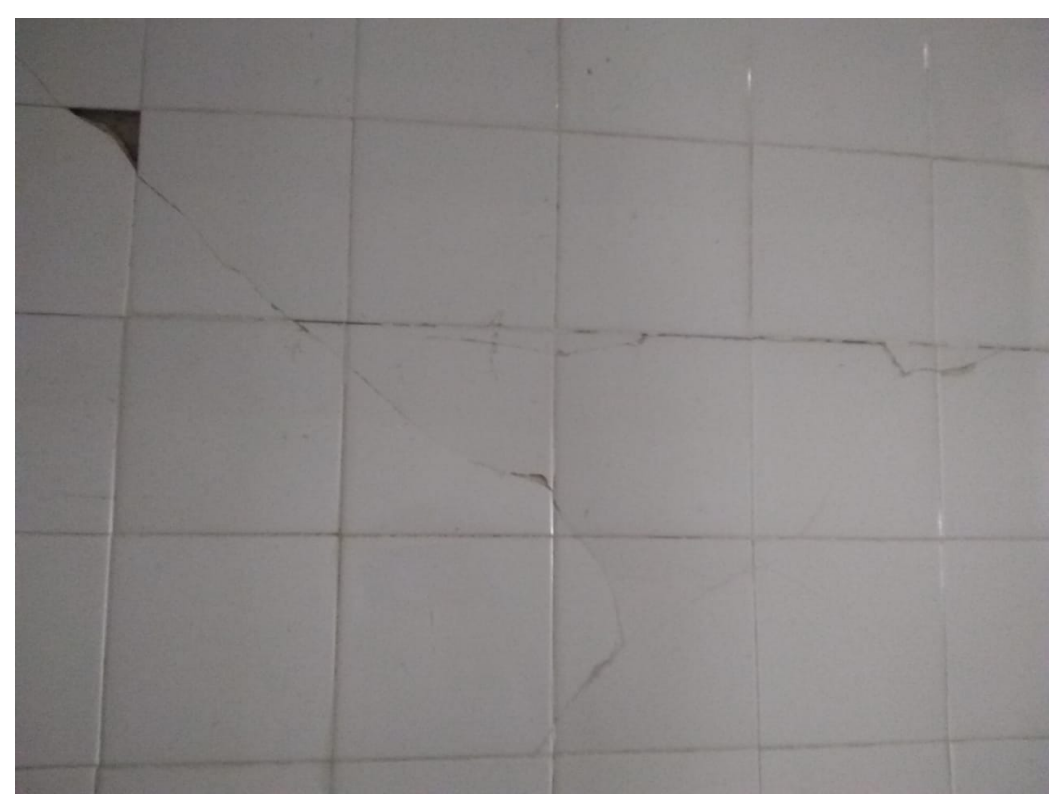

Figure 2. Cracks in ceramic tiles caused by settlement.

As for the problem caused by settlements, Velloso and Lopes (2010) consider that it occurs due to problems related to soil-structure interaction, also highlighting that a greater stiffness of the foundation will cause more uniform settlements, stressing that when a foundation is combined or associated (more than one column), the differential settlements will consequently be lower.

Also according to Velloso and Lopes (2010), the soil settlements are generally much higher than the deflections that a pile can support. Therefore, the use of inclined piles in soils that settle should be avoided..

\subsubsection{Alkali-aggregate reaction}

The alkali-aggregate reaction (AAR) is a phenomenon that occurs in reinforced concrete and develops from the combination of three agents: alkalis from cement, reactive or potentially reactive aggregate, and the constant presence of moisture (MIZUMOTO, 2009). From this combination will arise often irreversible damage.

\subsubsection{Attack by sulfates}

The attack by sulfates is a form of attack on concrete that occurs when the structure is in contact with water or soil with the presence of sulfate $\left(\mathrm{SO}_{4}\right)$. The sulfates react with the cement components, generating expansive products, thus creating dilatations that will degrade and crack the concrete (SANTOS, 2019).

\subsubsection{Setback by pressure superposition}

According to Marinho (2019), buildings with high load, i.e., those that have a large area of influence of the stress bulb, close to other buildings with direct superficial foundations, can cause an overlap of the bulbs of the buildings. When this occurs, settlements will appear in the buildings, especially when they are older. The author adds that when this type of settlement occurs, cracks and fissures may appear in the construction, and may even affect its safety.

\subsubsection{Setbacks due to soil problems}

According to Silva Junior (2017), the choice of the foundation depends on the characteristics of the soil, its interaction with the foundation, considering the characteristics of the soil layers below the support elevation of the foundation, in order to avoid problems of foundation instability. 
In this sense, the negative friction generated on compressible soils can generate soil settlements. Other causes of soil settlements are linked to the lowering of the water table, and the denting of sensitive soft clays, which can be generated by pile driving (MAGALHÃES, 2004).

\subsection{Pathology of reinforced concrete structures}

For years, concrete was considered to be an extremely durable material, due to old structures that still keep a good appearance, thus demonstrating a good state of conservation. However, recent deteriorations in structures have led the technical and scientific community to question the pathologies of reinforced concrete. There are some advances in research, especially consolidated in some technical standards for construction, involving the specification of materials, performance, and construction techniques, aiming to increase the final quality of the product and reduce costs as much as possible (GONÇALVES, 2015).

Within this context, the Brazilian standard NBR 6118 (ABNT, 2014), which covers the durability of materials and structures and also recommends some possible corrective procedures, defines design life as the period of time during which the characteristics of concrete structures are maintained, provided that the requirements of use and maintenance prescribed by the designer and builder are met, as well as the execution of necessary repairs arising from accidental damage. The main types of pathologies found in reinforced concrete structures are detailed below.

\subsubsection{Mold}

Mold is a type of pathology that usually appears on facades, and can also appear in other areas of the construction. According to Macedo (2017), it occurs when there is an accumulation of fungi of the most varied types in the coating layers, which generate colonies that feed on organic materials. The ideal places for their proliferation are areas that present humidity by condensation and where there is no running water.

According to Sena et al. (2020), the presence of mold indicates a high degree of humidity, which can bring degradation to the structure as a result of vegetation that grows through small cracks and expansion joints, causing a mechanical type interaction. Figure 3 exemplifies this type of pathology.

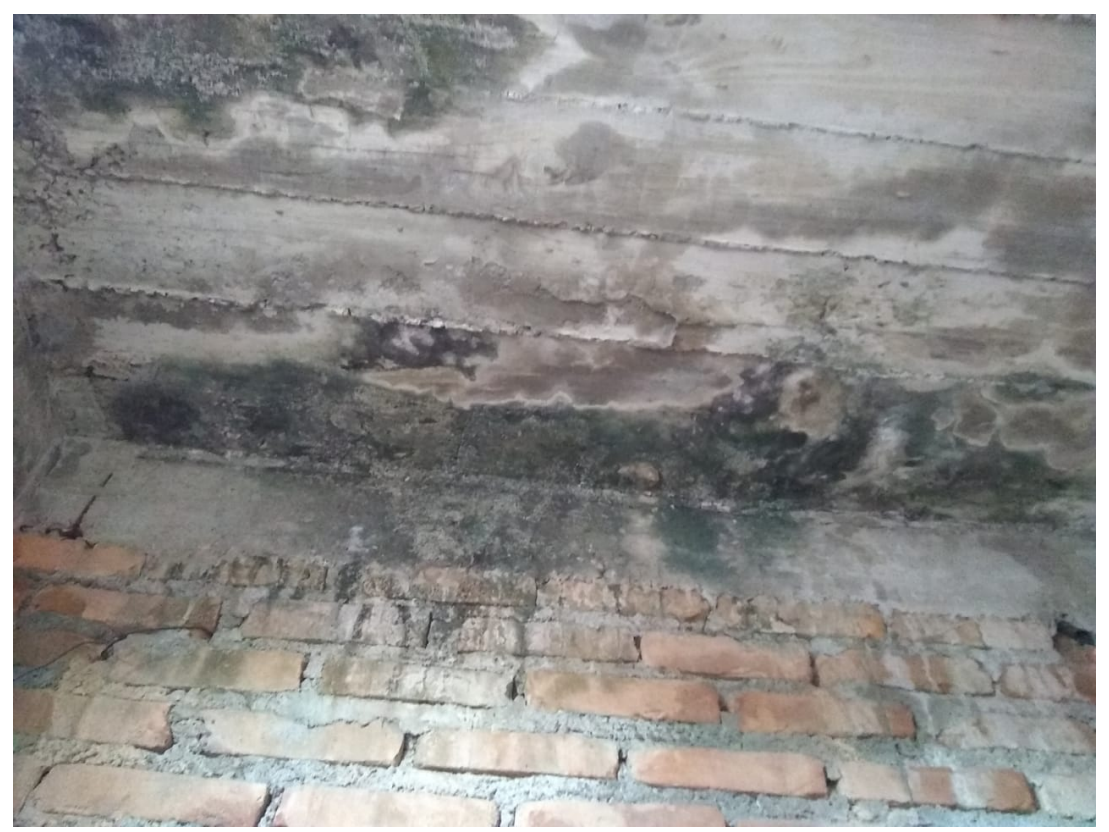

Figure 3. Reinforced concrete slab with mold and stains. 


\subsubsection{Efflorescence and leaching}

According to Bertolini (2010), "leaching (pure and acidic waters, expansion by sulfates or magnesium, expansion by alkali-aggregate reaction, deleterious surface reactions) is one of the most important mechanisms in the deterioration of concrete structures".

Macedo (2017) defines efflorescence and leaching as acidic water or water with a high concentration of chlorides and sulfates that, when entering the capillary pores of the concrete, dissolves the calcium hydroxide of the cement paste, which can subsequently react with carbon dioxide from the air, forming calcium carbonate $\left(\mathrm{CaCO}_{3}\right)$.

Within this context, Bolina et al. (2019) explain that through leaching the porosity of concrete is increased, and if they are insoluble and expansive, they will cause deterioration of the material by causing cracking. In addition, the leaching process can be originated by rainwater and its most frequent consequence is the disintegration of the cement paste.

\subsubsection{Cracks}

Cracks are openings that affect the surface of the structural element, causing the entrance of aggressive agents to the structure. In concrete constructions, cracks may appear soon after their execution or take years to appear. Their causes are variable and generally difficult to diagnose. Cracks are designated as the rupture that occurs in concrete under mechanical or physicalchemical actions (GONÇALVES, 2015).

NBR 6118 (ABNT, 2014) establishes the following values to determine the degree of its environmental aggressiveness: for aggressiveness class I, the maximum opening of $0.4 \mathrm{~mm}$; for aggressiveness class II and III, the maximum opening of $0.3 \mathrm{~mm}$; for aggressiveness class IV, the maximum opening of $0.2 \mathrm{~mm}$; in specific cases, these limits must be reduced.

\subsubsection{Segregation}

According to Gonçalves (2015), the concrete launch height is a point of attention to the execution of concrete elements, reinforced or not. The author states that the concreting of parts with more than two meters in height should be carried out carefully, in order to avoid segregation (concreting nests) of the coarse aggregates in the lower regions of the part, originating pits or voids. Moreover, compaction can also generate segregation problems.

\subsubsection{Corrosion of reinforcement}

Steel when used in structures can be a victim of corrosion, producing stresses that the concrete cannot resist. Consequently, cracks are formed. And when it comes to reinforcements that are closer to the surface they will be more exposed to the action of external agents, generating more corrosion (GONÇALVES, 2015).

The cracks in reinforced concrete need to be treated properly, blocking the corrosion process to not allow their aggravation. One should seek to identify, diagnose and correct the true causes of the problem (GONÇALVES, 2015).

According to NBR 6118 (ABNT, 2014), the acceptable limits for the opening of cracks caused by corrosion are $0.1 \mathrm{~mm}$, for unprotected parts in an aggressive environment; $0.2 \mathrm{~mm}$, for unprotected parts in a non-aggressive environment; and $0.3 \mathrm{~mm}$, for protected parts.

Figure 4 and Figure 5 exemplify the corrosion process in the reinforcement of reinforced concrete structural elements. 


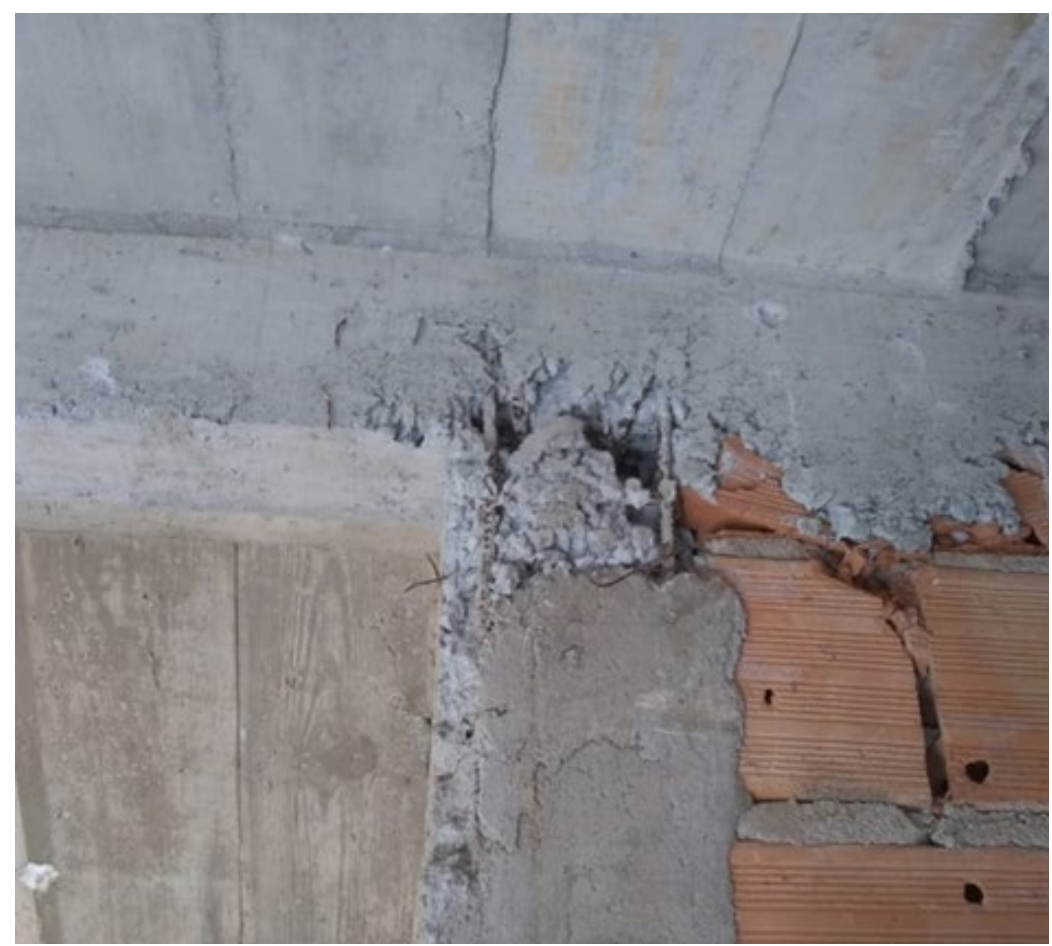

Figure 4. Drill in the beam-column connection that favors the corrosion of the reinforcement.

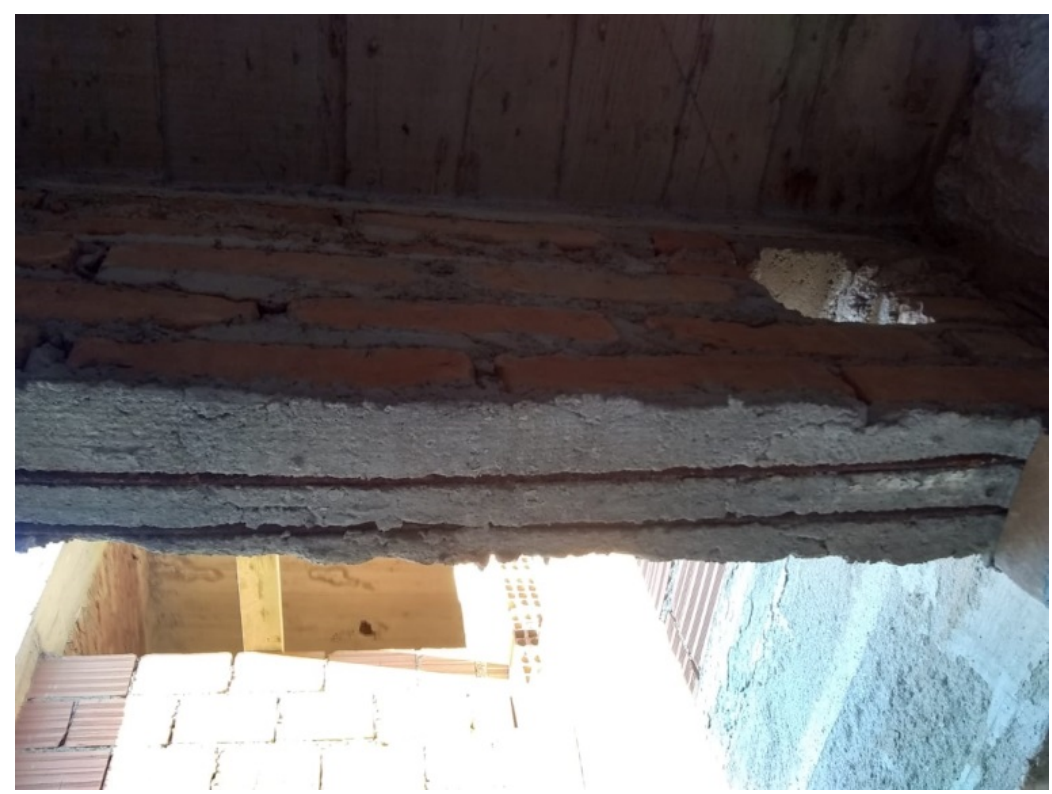

Figure 5. Exposed reinforcement in the frame support beam.

\subsubsection{Deterioration of reinforced concrete}

The Brazilian standard NBR 6118 (ABNT, 2014) defines durability as the ability of the structure to resist environmental influences foreseen and defined jointly by the author of the structural project and the contractor, at the beginning of the project preparation work.

According to Santos (2019), the degradation of reinforced concrete structures occurs by the penetration of substances in the form of gases, vapors, and liquids, through pores and cracks. Therefore, it is understood that permeability is the main determinant of vulnerability to external agents.

Furthermore, concrete deterioration rarely occurs due to an isolated cause, since concrete can sometimes be satisfactory, but a single additional adverse factor can cause its deterioration. 


\subsection{Masonry pathology}

Masonry can be defined as elements made up of units called components, such as ceramic or concrete blocks, which are usually joined by binding material but can also be embedded (SENA et al., 2020). Also according to these authors, masonry can be classified as structural or sealing, which have different design life, and the main types of pathologies presented by these are:

- Cracks due to thermal movement - occur in the structural elements, especially in upper floors, and induce tensile and shear stresses in the seals;

- Cracks due to the absence or inefficiency of lintels and counter-verges - the lintels and counter-verges are regulated by the Brazilian standard NBR 8545 (ABNT, 1984). They can be executed by means of blocks, channels, pre-molded, and even executed directly on-site by means of formwork, recommending that they have at least two bars along their length. When these elements are not executed correctly, cracks may occur. Figure 6 shows a crack due to the lack of lintels and Figure 7 due to the lack of counter lintels.

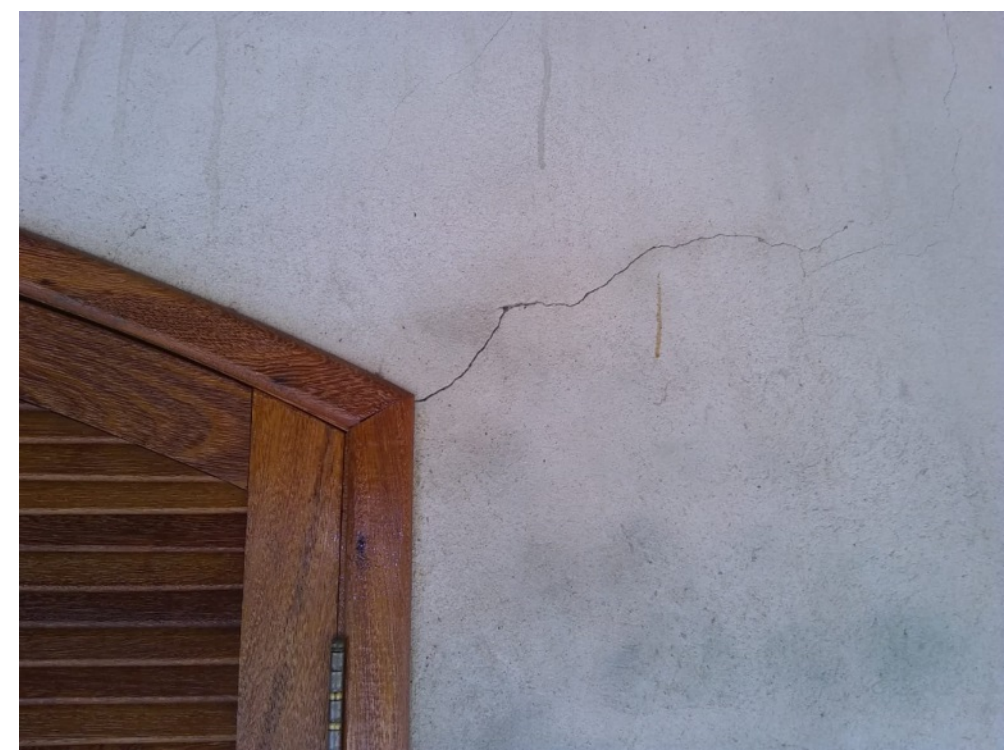

Figure 6. Crack in lintels.

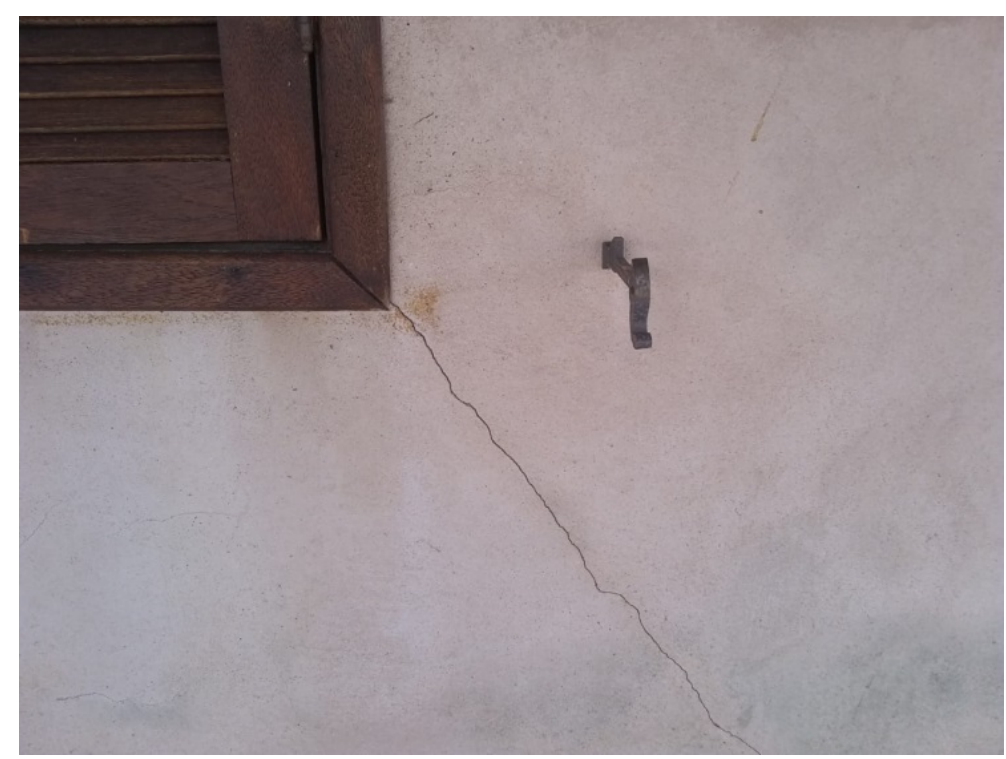

Figure 7. Crack in counter lintels. 
- Cracks due to differential settlements - may be noticed by the presence of openings in the structure, but the most recurrent ones are in the masonry, which, as they are less resistant elements, may crack more easily. Their possible causes may be related to buildings built on deformable layers and superficial embankments, overlapping stress bulges, proximity to unstable slopes, the influence of humidity or water table on the soil, among others;

- Cracks due to failure in the wedging - early wedging or with inadequate materials may cause cracks in the masonry. This can occur due to the efforts induced in the masonry by the deformations of the structural elements above it;

- Pathological manifestations from humidity - humidity is linked to the amount of water absorbed by a material, depending on its porosity and capillarity. Most construction materials are hygroscopic, absorbing or losing moisture according to the increase or decrease in relative humidity. This moisture may act as a degradation material or components through expansion or shrinkage. Figure 8 shows moisture occurring in a wall as a result of a leak in the hydraulic installations, while Figure 9 shows moisture due to capillary rise from the ground.

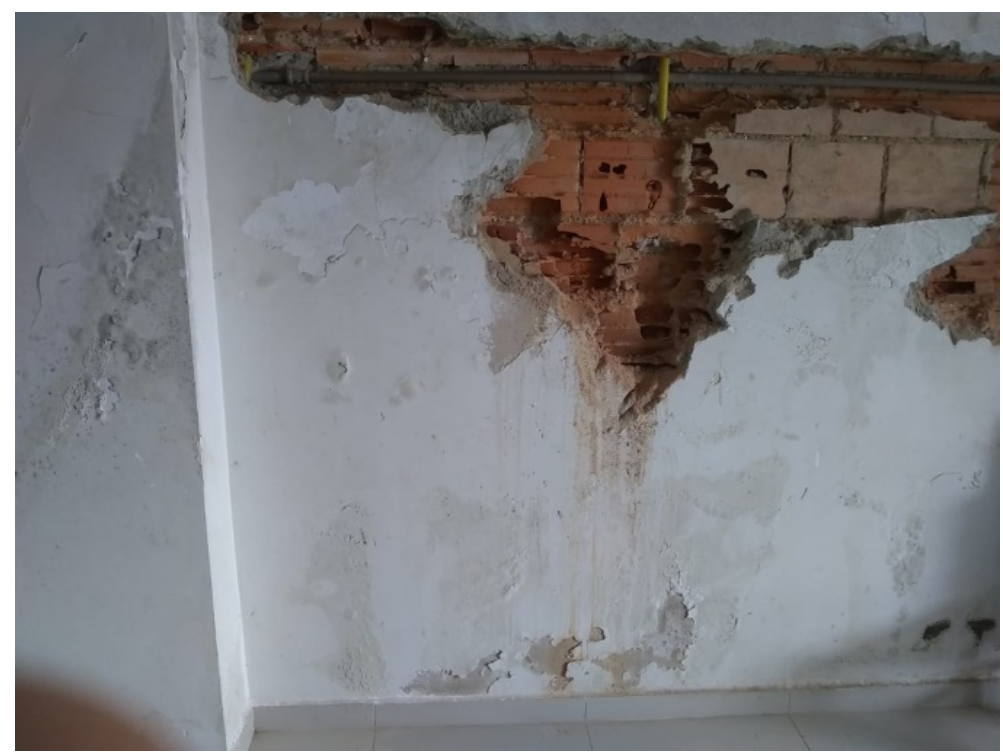

Figure 8.Moisture due to leakage in a water tank.

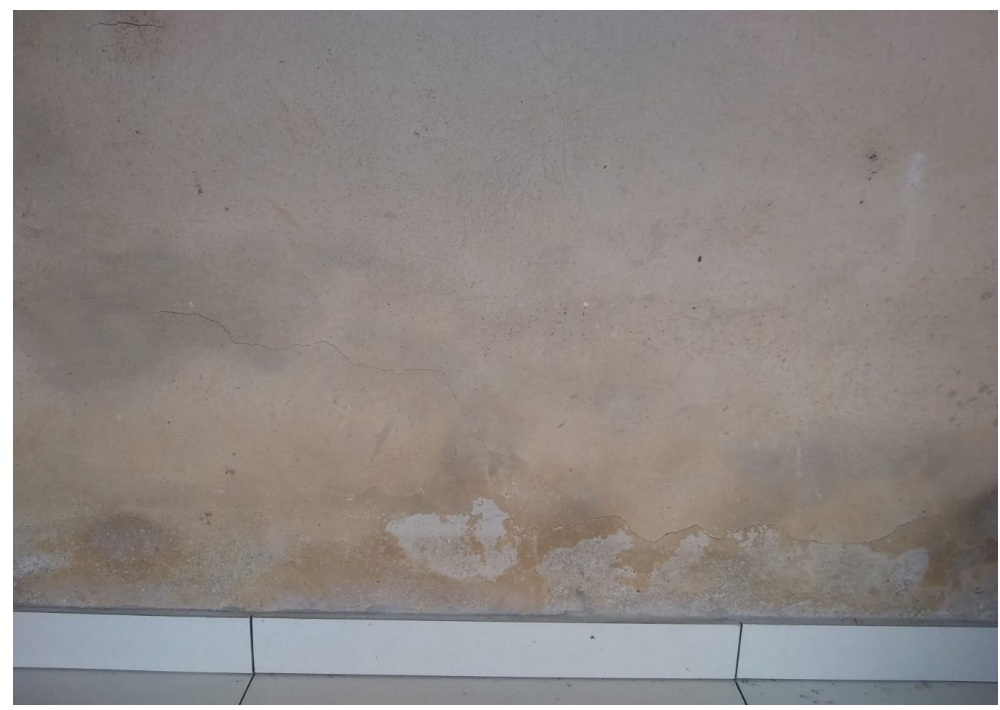

Figure 9.Moisture due to rising dampness from the ground. 


\subsubsection{Layers and constituent materials of the grout and ceramic covering systems}

The grout and ceramic systems are the most used in Brazil, because, in addition to aesthetics, they have good durability if they are well done. When they present problems, they are usually related to a lack of care and can be found at any stage of construction (SENA et al. 2020).

As for grout coatings, Thomaz (1989) also considers the importance of the Brazilian standard NBR 13529 (ABNT, 2013), which defines them as the covering of a surface with one or more superimposed layers of grout, able to receive a decorative finish or constitute a final finish.

These coating systems are preceded by the substrate (or base) and roughcast layers, as well as by the main constituent core based on grout, which is composed of mixtures of one or more binders. There are differences in these layers that are related to finishing and execution. For external ceramic coatings, the Brazilian standard NBR 13755 (ABNT, 2017) specifies their upper limits as $50 \mathrm{~mm}$ and lower limits as $20 \mathrm{~mm}$.

\subsubsection{Main pathological manifestations in grout coating systems}

Coating problems generally originate from a lack of control in its various stages, such as in grout coatings. The deterioration of these coatings can occur in three ways: physical-mechanical, chemical, and biological. These effects usually overlap, making it difficult to analyze the real cause of the problem, whose causative source may be related to the quality of the constituent materials, the composition of the grout mix, the executive processes, and external factors (SENA et al. 2020).

According to Masuero (2001), some technical standards referring to coating grouts must be respected, namely: NBR 13528 (ABNT, 2019), NBR 7200 (ABNT, 1988), NBR 13749 (ABNT, 2013), and NBR 13281 (ABNT, 2005).

According to Segat (2005), the occurrence of pathological manifestations on external facades usually comes from the lack of technical competence in construction work when executing the coating. Many times, it is related to water and additive dosage errors, execution of layers that are too thick or not thick enough, lack of grout uniformity, and even lack of substrate cleaning. This is why it is so important to adopt rigorous criteria when selecting the grouts that will compose the coating.

Within this context, Masuero (2001) points out that the main pathological manifestations of grout are cracks, detachment, and peeling, which occur especially in external cladding, and there may also be stains caused by humidity or microorganism colonies, as detailed below.

- Fissures - their cause is not unique. The problem usually results from the movement and/or deformation of the base on which the mixture is applied. This situation occurs at the interface between concrete and masonry, in the upper region of the masonry, or at stress concentration points, such as corners of openings. They are also linked to grout water loss;

- Dislocation and peeling - related to the lack of adherence of the coating to the base, depending on the occurrence of situations related to the characteristics of the surfaces, the type of grout used and the execution process, and weather conditions. For this reason, the substrate to be coated must present absorption that provides micro-anchorage, resulting from the penetration of the paste or grout into its pores, providing macro roughness, providing a greater area of contact of the mixture on the irregularities of the base;

- Stains and colonies of microorganisms - resulting from a series of factors, the most common reasons for this type of pathology are problems with infiltration, waterproofing, low-quality window frames, which allow rain to enter, and leaks from the hydraulic system.

To correct these pathological manifestations with grout, it is necessary to investigate each case. If the cracks are caused by the structure's movement, for example, the existing deformations must be analyzed. The correction will involve the use of joints or screens in the coating, a solution specified based on the characteristics of each project. When it is the case of detachment, the 
coating must be removed and re-executed. The procedure must be redone from the beginning, starting with the preparation of the base and continuing through the execution process, including the correct specification of the grout (MASUERO, 2001).

For prevention, Bolina et al. (2019) explain that the best way to avoid the appearance of pathological manifestations is by performing the proper coating project, which will present all the technical specifications of the materials to be used. The project should also foresee the correct processes of execution and control, aiming to obtain the satisfactory performance of the coating.

\subsubsection{Main pathological manifestations in ceramic tiling}

Ceramic tiles are also one of the types of tiling with the highest incidence of pathologies, which, according to Sena et al. (2020), have become less frequently used due to this factor. Even so, they are still among the most commonly used types of coating.

These coatings are regulated by the Brazilian standard NBR 13755 (ABNT, 2017), which specifies the procedures related to the design, execution, inspection, and acceptance of ceramic tiles.

According to Campante and Baía (2003), one of the main causes of pathologies in ceramic tiles is poorly executed laying. In addition, it is very common that in the design phase the execution of the façade cladding is not specified, and this lack of planning and, often, of skilled labor, end up resulting in pathologies. The author indicates that the main causes are usually: inadequate preparation of the base, insufficient wetting of the base, compromising the hydration of the grout's cement, roughcast prepared with fine sand, grout with excessive thickness, and grout with excessive cement.

Among the main problems found in both ceramic and grout coverings are efflorescence and cracks. Ceramic detachment, exemplified in Figure 10, is among the anomalies that most occur in ceramic tiles.

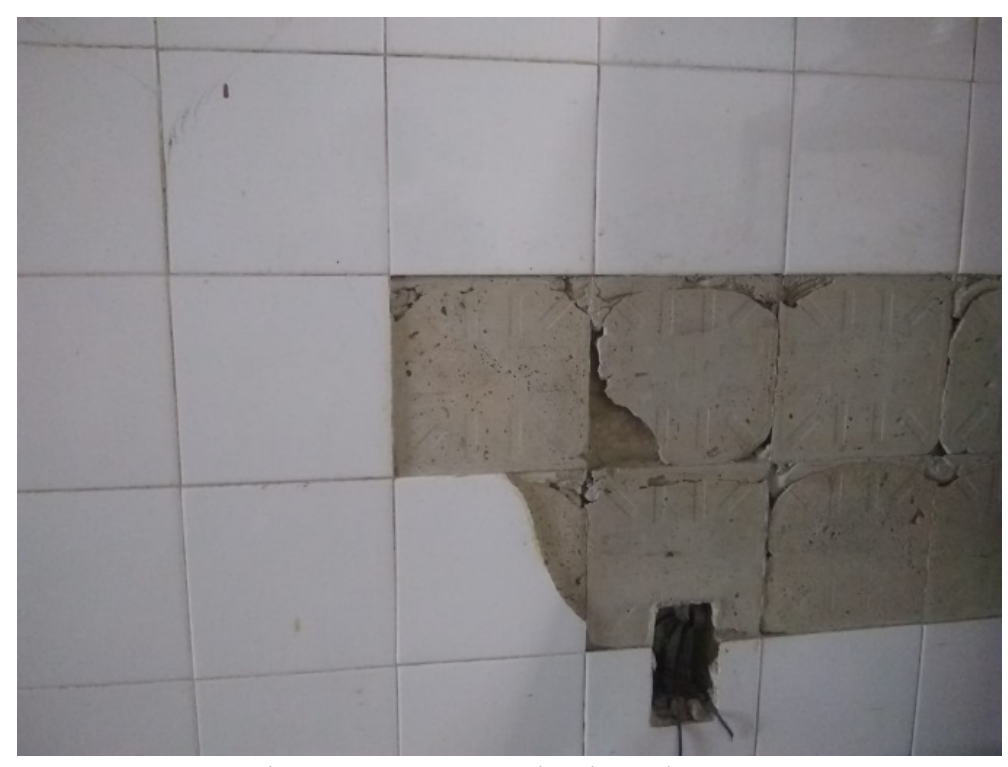

Figure 10. Ceramic detachment.

Still, within this context, Santos (2019) states that the absence of proper maintenance in buildings is responsible for a variety of anomalies, which in turn are the cause of material damage and sometimes personal injury. Maintenance activities performed in accordance with the real needs presented by a previously inspected building tend to make it return to conditions similar to those of its initial state. Thus, it is the responsibility of the builder to prepare a building maintenance manual for the property. 
The durability and performance of the facades depending on the decisions made in the various stages of the building production process, i.e., planning, design, specification, materials, execution, and use (SANTOS, 2019).

\section{CONCLUSIONS}

From the literature review conducted in this paper, it is ratified the statement that the pathologies in civil construction can have various causes and require different interventions. It is noteworthy that, because it is a very extensive topic, only the main types of pathological manifestations were addressed.

Among the different parameters that contribute to the degradation of buildings, we can mention temperature variations, chemical reactions, vibrations, erosion, and especially the phenomenon of reinforcement corrosion in reinforced concrete, a very important pathological phenomenon that contributes greatly to the deterioration of the construction. These phenomena can manifest themselves from the foundations to the final finish of a building, as explained in this paper.

Therefore, it is pertinent to note that there are several mechanisms and causes for the degradation of buildings. Thus, some care taken in the stages of project conception and execution of the work can considerably increase the durability of the construction. In addition, the owner and the user also have a share of responsibility for the durability and service life of the building and should perform regular maintenance and be aware when anomalies appear.

\section{REFERENCES}

Associação Brasileira de Normas Técnicas. 2014. NBR 6118. Projeto de estruturas de concretoProcedimento. Rio de Janeiro.

Associação Brasileira de Normas Técnicas. 1988. NBR 7200. Execução de revestimento de paredes e tetos de argamassas inorgânicas - Procedimento. Rio de Janeiro.

Associação Brasileira de Normas Técnicas. 1984. NBR 8545. Execução de Alvenaria sem função estrutural de tijolos e blocos cerâmicos. Rio de Janeiro.

Associação Brasileira de Normas Técnicas. 2005. NBR 13281. Argamassa para assentamento e revestimento de paredes e tetos - requisitos. Rio de Janeiro.

Associação Brasileira de Normas Técnicas. 2019. NBR 13528-3. Revestimento de paredes de argamassas inorgânicas - Determinação da resistência de aderência à tração. Parte 3:

Aderência superficial. Rio de Janeiro.

Associação Brasileira de Normas Técnicas. 2013. NBR 13529. Revestimento de Paredes e Tetos de Argamassas Inorgânicas - Terminologia. Rio de Janeiro.

Associação Brasileira de Normas Técnicas. 2013. NBR 13749. Revestimentos de paredes e tetos de argamassas inorgânicas - Especificações. Rio de Janeiro.

Associação Brasileira de Normas Técnicas. 2017. NBR 13755. Revestimento de paredes externas e fachadas com placas cerâmicas e com utilização de argamassa colante-Procedimento. Rio de Janeiro. 
Bertolini, L. (2010), “Materiais de Construção: Patologia. Reabilitação. Prevenção”. Oficina de Textos, São Paulo.

Bolina, F. L., Tutikian, B. F., \& Helene, P. (2019). Patologia de estruturas. Oficina de Textos.

Campante, E. F.; Baía, L. M. (2003), “Projeto e execução de revestimento cerámico". São Paulo: O Nome da Rosa.

Castro, U. R. (2007), "Importância da manutenção predial e as ferramentas para sua execução". Federal University of Minas Gerais. Belo Horizonte.

Gonçalves, E. A. B. (2015), “Estudo de patologias e suas causas nas estruturas de concreto armado de obras de edificações". Rio de Janeiro.

Macedo, E. A. V. B. (2017), "Patologias em obras recentes de construção civil: análise crítica das causas e consequências". Federal University of Rio de Janeiro. Rio de Janeiro.

Magalhães, E. F. (2004), "Fissuras em alvenarias: configurações típicas e levantamento de incidências no Estado do Rio Grande do Sul”. Master Thesis, School of Engineering, Federal University of Rio Grande do Sul, Porto Alegre.

Marinho, R. D. O. (2019), "Desenvolvimento de um software para dimensionamento de fundações do tipo tubulão para torres de linhas de transmissão".

Masuero, A. B. (2001). Estabilização das escórias de aciaria elétrica com vistas a sua utilização como substituição ao cimento.

Milititsky, J.; Consoli, N. C.; Schnaid, F. (2015), “Patologia das fundações”. 2. ed. São Paulo: Oficina de textos.

Mizumoto, C. (2009), "Investigação da reação álcali-agregado (RAA) em testemunhos de concreto e agregados constituintes".

Oliveira, D. F. (2013), “O Conceito de Qualidade Aliado às Patologias na Construção Civil”. Federal University of Rio de Janeiro. Rio de Janeiro.

Santos, Y. M. (2019), “Análise de patologias de pisos cerámicos”. Management Bulletin, v. 10, n. 10, p. 31-42.

Sena, G. O. et al. (2020), "Patologia das Construções". Salvador.

Silva Júnior, I. V. D. (2017) “Análise dos efeitos do recalque em um edifício de concreto armado com apoios elásticos e discretizados".

Thomaz, E. (1989), “Trincas em Edifícios: causas, prevenção e recuperação”. São Paulo: Pini.

Velloso, D. A.; Lopes, F. R. (2010), “Fundações: critérios de projeto, investigação do subsolo, fundações superficiais, fundações profundas". Oficina de Textos. São Paulo. 